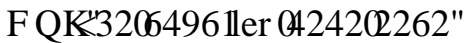 \\ Çocuklarda Arı (Hymenoptera) Sokmalarına Bă̆lı Reaksiyonların Prevalansı
}

\section{The Prevalence of Reactions Related to Insect (Hymenoptera) Stings in Children}

1 Bursa Uludağ Üniversitesi, Çocuk Alerji BD, Bursa

Sorumlu yazar yazışma adresi: Yakup CANITEZ: Bursa Uludağ Üniversitesi Tıp Fakültesi, Çocuk Alerji Bilim Dalı, Bursa, Türkiye

E-mail:canitez@uludag.edu.tr

Geliş tarihi/Received: $\quad 8.12 .2020$

Kabul tarihi/Accepted: 10.12 .2020

Yayın hakları Güncel Pediatri'ye aittir.

GüncelPediatri2020;18(3):457-469
Yakup Canitez (0000-0001-8929-679X) ${ }^{1}$, Nihat Sapan (0000-0002-76018392) ${ }^{1}$

\section{$\ddot{O} Z$}

GíRIŞ ve AMAÇ: Çocuklarda arı (hymenoptera) sokmasına bağlı gelişen reaksiyonların prevalanslarını araştıran az sayıda çalışma bulunmaktadır. $\mathrm{Bu}$ çalışma çocuklarda genel populasyonda arı sokmasına bağlı gelişen sistemik, geniş lokal, lokal reaksiyonların görülme sıklıklarının araştırılması amacı ile planlanmıştır.

YÖNTEM ve GEREÇLER: Bu çalışmada Bursa il merkezi ve köylerinde dört ayrı ilköğretim okulu rastgele örnekleme yöntemiyle araştırma için seçildi. Çalışmada anket yöntemiyle 6-15 yaş grubunda yer alan toplam 3243 çocuk değerlendirildi.

BULGULAR: Çocukların 1714'ü $(\% 52,9)$ erkek, 1529'u $(\% 47,1)$ kız idi.

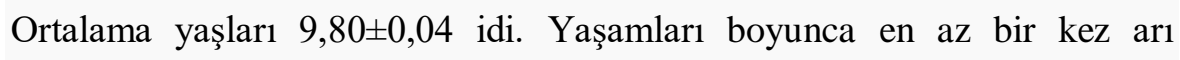
tarafından sokulan çocukların sayısı $1992(\% 61,4)$, son 12 ay içinde sokulan çocukların sayısı ise $711(\% 21,9)$ olarak bulundu. Çalışma populasyonunda arı sokmasına bağlı görülen reaksiyonların sıklığı (yaşam boyu prevalanslar1), sistemik reaksiyon 9 çocukta $(\% 0,3)$, geniş lokal reaksiyon 19 çocukta $(\% 0,6)$, lokal reaksiyon 1964 çocukta $(\% 60,5)$ saptandı. Erkek çocuklarda kızlara göre yaşamları boyunca istatistiksel anlamlı olarak daha yüksek sayıda sokulma sayısı ve sistemik veya geniş lokal reaksiyon görülme oranlar1 saptand1 (sırasiyla $\mathrm{p}<0,001, \mathrm{p}<0,05, \mathrm{p}<0,01$ ).

TARTIŞMA ve SONUÇ: Bölgemizde 6-15 yaş grubu çocuklar arı sokmaları ile sık olarak karşılaşmaktadırlar. Arı sokmasına bağlı reaksiyonlar belli oranlarda görüldüğü için bu verilerin olası reaksiyonları tanımlama ve yaklaşım açısından dikkate alınması uygun olacaktır. 
Anahtar Kelimeler: Çocuk, arı, hymenoptera, alerji, epidemiyoloji.

\section{ABSTRACT}

INTRODUCTION: There has a few number of studies in children that looked for the prevalence of reactions caused by insect (hymenoptera) stings. This study was planned with the aim of investigating the prevalence of systemic, large local and local reactions due to hymenoptera stings in the general population in children.

MATERIALS and METHODS: In this study, four different schools in Bursa city center and its villages were selected for research by random sampling method. A total of 3243 children in the 6-15 age group were evaluated using the questionnaire method in the study.

RESULTS: Of the children, 1714 (52.9\%) were boys and 1529 (47.1\%) were girls. The mean age was $9.80 \pm 0,04$ years. The number of children who were stung at least once in their lifetime was $1992(61.4 \%)$, and the number of children who were stung in the last 12 months was 711 (21.9\%). The frequency of reactions due to hymenoptera stings in the study population (lifetime prevalences), systemic reaction in 9 children (0.3\%), large local reaction in 19 children (0.6\%), local reaction in 1964 children $(60.5 \%)$ were found. There were higher numbers of lifetime hymenoptera sting and rates of systemic or large local reactions in boys compared to girls $(\mathrm{p}<0,001, \mathrm{p}<0,05, \mathrm{p}<0,01$ respectively).

CONCLUSIONS: In our region, children between the ages of 6-15 frequently encounter hymenoptera stings. Since reactions due to hymenoptera stings occur at certain rates, it would be appropriate to consider these data in terms of defining possible reactions and approach.

Key words: Child, bee, hymenoptera, allergy, epidemiology. 


\section{GíRIŞ}

Arı allerjisi IgE aracılığıyla gelişen alerjik hastalıklardan biridir (1). Ar1 sokmaları sonrası gelişen sistemik allerjik reaksiyonlar, anafilaksi nedenleri arasında sik görülen nedenlerden birisidir $(2,3)$. Anafilaktik reaksiyonlar yaşamsal tehlikelere ve ölümlere yol açabilmeleri nedeniyle ciddi bir sağlık problemi olarak ele alınmaktadır $(4,5)$.

Arılar, Insecta (böcekler) sınıfının Hymenoptera (zar kanatlılar) takımı içinde yer alan sokan böceklerdendir. Hymenoptera takımı içinde; bal arıları (Apidae), yaban arıları (Vespidae) ve karıncalar (Formicidae) familyaları yer alır $(1,4,5)$.

Arı sokmaları sonrası gelişen erken reaksiyonlar; lokal (normal), geniş lokal, sistemik reaksiyonlar olarak 3 gruba ayrılmaktadır $(4,6,7)$. Lokal reaksiyon; arı sokmasını takiben derinin sokulan bölgesinde lokal ağrı, eritem ve şişlik ile karakterize reaksiyondur $(1,2)$. Lokal reaksiyon genellikle birkaç saat içinde geriler, soğuk kompres ve analjezik dışında tedavi gerektirmez $(1,2)$. Geniş lokal reaksiyon; arının soktuğu bölgede $10 \mathrm{~cm}$ veya daha büyük boyutta şişlik ve eritem ile karakterizedir $(4,6,8)$. Genellikle 2448 saat sonra şişlik ve eritem en yüksek düzeye ulaşır, düzelmesi 1 hafta 10 güne kadar uzayabilir (4,68). Bazen bütün bir ekstremiteyi tutabilir, reaksiyon ağır ise bitkinlik ve bulantı ile birlikte olabilir $(1,7)$. Literatürde yer alan araştırmalarda erişkin genel populasyonlarda geniş lokal reaksiyon görülme prevalansının \%1,5-7,4 arasında bulunduğu bildirilmektedir (9-13). Literatürde ülkemizde çocuk yaş gruplarında geniş lokal reaksiyon görülme prevalansı ile ilgili araştırmalar mevcut değildir. Yurtdışında ise genel çocuk populasyonlar üzerinde, geniş lokal reaksiyon görülme prevalansı ile ilgili çalışmalar az sayıdadır, sadece 3 çalışmaya ait veriler mevcuttur; İtalya'da \% 0,9 (14), İsrail'de \% 11,5 (15), İrlanda'da $\%$ 2,2 (16) olarak bildirilmiştir.

Sistemik reaksiyon hayatı tehdit eden sonuçlar oluşturabilir (1). Sistemik reaksiyonlar hafif ve ağır olarak 2'ye ayrılabilir $(1,17,18)$. Hafif sistemik reaksiyonlar; daha sık görülür ve genellikle kaşınma, flushing, ürtiker veya anjioödem şeklinde ortaya çıkar $(1,4,7)$. Ağır sistemik reaksiyonlar (anafilaksi); özellikle solunum ve kardiyovasküler sistemi tutan bulgularla birliktedir (hafif sistemik reaksiyonda görülebilen bulgularla çoğunlukla birlikte görülebilir) (4). Üst solunum yolu ödemi (farinks, larinks veya epiglottisi tutan), havayolu tutulumu (dispne, wheezing), bulant1, kusma, karın ağrısı, inkontinans, bilinç kaybı, kardiyovasküler sistem tutulumu sonucu hipotansiyon, şok, ölüm görülebilir $(1,4,6,7)$.

Literatürde erişkin yaş grubunda genel populasyonlar üzerinde yapılan çalışmalarda sistemik reaksiyon görülme oranları \%1,16-4 arasında bildirilmektedir (9-13,19-22). Ülkemizde ise erişkinler üzerinde anket yöntemiyle yapılmış olan iki çalışmada \%2,2-\%4,1 oranlarında sistemik reaksiyon bildirilmiştir $(23,24)$. Çocuk yaş gruplarında ise genel populasyonlar üzerinde sistemik reaksiyon prevalansını araştıran çalışma sayısı oldukça azdır. Ülkemizde ise çocuklar üzerinde daha önce yapılmış olan tek çalışmada; 1998 y1lında, Ankara'da 6-13 yaş grubu 738 ilkokul öğrencisinde anket yöntemiyle \%2 oranında sistemik reaksiyon bildirilmiştir (25). Türkiye dışında diğer ülkelerde ise çocukluk çağında ve hepsi de anket 
yöntemi ile yapılmış olan araştırmalarda çocukluk yaş gruplarında sistemik reaksiyon prevalanslarının \%0,15-\%2,5 arasında değiştiği bildirilmektedir (14-16,26-29).

Literatürde çocukluk çağında arı alerjisine bağlı sistemik reaksiyon ve geniş lokal reaksiyon prevalanslarını araştıran az sayıda çalışma mevcuttur. Türkiye'de çocuk yaş gruplarında arı sokmalarına bağlı geniş lokal reaksiyon görülme prevalansı ile ilgili araştırma mevcut olmaması, sistemik reaksiyon görülme prevalansı ile ilgili sadece bir çalışma (25) bulunması nedeniyle; Türkiye'nin kuzeybatı bölgesinde yer alan Marmara bölgesinde, geniş bir çocuk populasyonunda çocukların arı sokmalarına maruz kalma sıklığını, arı sokmalarına bağlı reaksiyonların (lokal, geniş lokal, sistemik reaksiyonlar) prevalanslarını, ilişkili faktörleri ve arı sokmalarından sorumlu olarak tanımlanan arı türlerini araştırmak amaciyla planlanmıştır.

\section{GEREÇ ve YÖNTEM}

Bursa il merkezinde 1 ve il merkezine bağlı köylerde 3 ayrı okul olmak üzere toplam 4 okul rastgele örnekleme yöntemiyle tarafımızca yürütülen arı alerjisi araştırmasının 1. basamağı olan bu epidemiyolojik çalışma için seçildi. Okullarda 6-15 yaş grubunda toplam 3265 çocuğa, tarafımızdan hazırlanmış olan anket formları gerekli açıklamalar yapılarak verildi. Anket formlarını evlerinde anne ve babaları ile dikkatli bir şekilde yanıtlamaları istendi.

Anket formları aşağıda belirtilen başlıklarda ayrıntılı soruları içermekteydi;

a) demografik bilgiler; yaş, cinsiyet, yaşanılan bölge,

b) yaşam boyunca arı tarafindan sokulma, var ise toplam kaç kez, arı cinsleri, son 12 ay içinde arı tarafindan sokulma, var ise kaç kez, arı cinsleri,

c) arı tarafindan sokulma sonrası görülen reaksiyonların özelliği; lokal, geniş lokal, sistemik reaksiyonlardan hangilerinin görüldüğ̈̈ ile ilgili açıklamalı sorular,

d) aile bireylerinde (birinci derece akrabalarda) arı alerjisi öyküsü (arı sokması sonucu geniş lokal veya sistemik reaksiyon görülen bireyler),

e) çocukta alerjik hastalık öyküsü (astım, alerjik rinit, atopik dermatit, gıda alerjisi, ürtiker) varlığı,

f) aile bireylerinde (birinci derece akrabalarda) alerjik hastalık öyküsü (astım, alerjik rinit, atopik dermatit, gıda alerjisi, ürtiker) varlığı.

Anket formlarında arı sokması sonrası görülen reaksiyonlar lokal (normal), geniş lokal, sistemik olarak 3 gruba ayrılarak ve ayrıntılı sorular kullanılarak tanımlandı. Ayrıca reaksiyonlar sonrası bir hekime veya sağlık kuruluşuna başvuru olup olmadığı ve uygulanan tedaviler sorgulandı.

Anket formlarında lokal reaksiyon; arı sokmasını takiben sokulan deri bölgesinde görülen ve saatler içinde içinde gerileyen lokal ağrı, eritem, şişlik (1-2 cm ile 8-9 cm arasında boyutlarda), geniş lokal reaksiyon; arının soktuğu bölgede $10 \mathrm{~cm}$ veya daha büyük şişlik ve eritem (genellikle 24-48 saatte en yüksek düzeye ulaşan ve sonraki günler içinde düzelmeye başlayan) olarak tanımlandı (1,4,6,7). En az bir kez geniş lokal 
reaksiyon tanımlayan (sistemik reaksiyon hiç tanımlamayan) çocuklar diğer arı sokmaları sonrasında lokal reaksiyon tanımlıyor olsalar da geniş lokal reaksiyon grubuna alındılar. Sistemik reaksiyonlar hafif ve ağır olarak 2 gruba ayrılarak tanımlandı. Olgular sadece ürtiker, flushing, kaşınma, anjiyoödem gibi bulgular varlığında "hafif sistemik reaksiyon" olarak; bulantı, kusma, karın ağrısı, bronkospazm, wheezing, dispne, hipotansiyon, şok gibi bulguların görülmesi ise (hafif sistemik reaksiyonda görülebilen deri bulguları ile birlikte veya deri bulguları olmadan) "ağır sistemik reaksiyon (anafilaksi)" olarak tanımlandı $(4,7,17,18)$. En az bir kez sistemik reaksiyon tanımlayan çocuklar diğer arı sokmaları sonrasında lokal veya geniş lokal reaksiyon tanımlıyor olsalar da sistemik reaksiyon grubuna alındılar. Anket formları değerlendirilerek eksik ve/veya yanlış veya şüpheli bilgi verildiği düşünülen çocukların aileleri ile tarafımızca telefon bağlantısı kurularak tekrar görüşüldü. Ayrıca bildirilen reaksiyonları anımsama veya tanımlamalarında hatalar olabileceği olasılığı düşünülerek arı tarafından sokulma sonucu geniş lokal veya sistemik reaksiyon görüldüğünü bildiren tüm çocuklar ve aileleri ile tekrar görüşüldü. Bu şekilde formlardaki bilgiler kontrol edildi ve gerekli düzeltmeler ve sağlamalar yapıldı.

Çalışma populasyonundaki 3243 çocuktan elde edilen veriler bilgisayar ortamına aktarılarak Bursa Uludă̆ Üniversitesi Tıp Fakültesi Biyoistatistik Anabilim Dalında istatistiksel hesaplamaları gerçekleştirildi. İstatistik hesaplamalarda SPSS 10.01 programı kullanılarak, ki-kare testi, Fisher'in kesin ki-kare testi, t-testi kullanıldı. İstatistiksel anlamlılık seviyesi için $\mathrm{p}<0,05$ eşik değer olarak kabul edildi. Sayısal ölçüm verileri aritmetik ortalama $(\mathrm{AO})$ ve \pm standart hata $( \pm \mathrm{SH})$ olarak belirtildi.

\section{SONUÇLAR}

Toplam 3265 çocuğa (6-15 yaş grubunda) anket formları verildi ve formlarını uygun şekilde doldurduğu görülen 3243 çocuk değerlendirmeye alındı. Formları uygun şekilde yanıtlamayan 22 çocuk çalışma dış1 bırakıldı. Ankete yanıt oranı \% 99,3 olarak gerçekleşti.

Çalışmaya alınan 3243 çocuktan oluşan populasyonun özellikleri ve elde edilen veriler Tablo 1'de

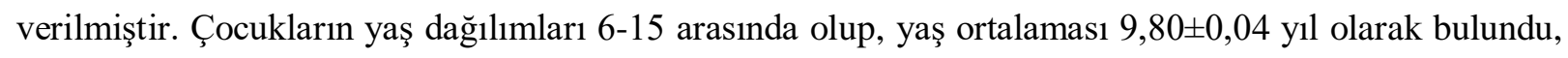
1714'ü $(\% 52,9)$ erkek, 1529'u (\%47,1) kız idi. Çalışma grubunda (n=3243) yaşamları boyunca en az bir kez arı tarafından sokulan çocuk sayısı $1992(\% 61,4)$ olarak bulundu. Son 12 ay içinde 711 çocuğun $(\% 21,9)$ arı tarafindan sokulduğu saptand.

Çalışma popülasyonunda arı sokmalarına bağlı görülen reaksiyonların görülme sıklıkları (yaşam boyu prevalansları) incelendiğinde, 3243 çocuğun 1964'ünde (\%60,5) lokal reaksiyon, 19'unda (\%0,6) geniş lokal reaksiyon, 9'unda $(\% 0,3)$ ise sistemik reaksiyon görüldüğü saptandı. Sistemik reaksiyon görülen 9 çocuktan 3'ünde $(\% 0,1)$ ağır sistemik reaksiyon, 6'sında $(\% 0,2)$ ise hafif sistemik reaksiyon görülmüştü. Çocukların 124'ünün $(\% 3,8)$ ailelerinde arı allerjisi öyküsü (arı sokmasına bağlı geniş lokal veya sistemik reaksiyon) vardı. Çocukların 409'unda $(\% 12,6)$, ailelerinin 604'ünde $(\% 18,6)$ alerjik hastalık öyküsü (astım, alerjik rinit, atopik dermatit, gıda alerjisi, ürtikerden en az biri) vardı. 
Tablo 1. Çalışma grubunun verileri $(\mathrm{n}=3243)$.

\begin{tabular}{|c|c|c|}
\hline & $\mathbf{N}$ & $\%$ \\
\hline Yaş ortalaması $(\mathrm{AO} \pm \mathrm{SH})^{*}$ & $9,80 \pm 0,04$ & \\
\hline Cinsiyet & 1714 & 52,9 \\
\hline $\mathrm{K} 1 \mathrm{z}$ & 1529 & 47,1 \\
\hline $\begin{array}{l}\text { Yaşam boyu en az bir kez arı sokma } \\
\text { öyküsü olan çocuklar }\end{array}$ & 1992 & 61,4 \\
\hline $\begin{array}{l}\text { Son } 12 \text { ayda arı sokma öyküsü olan } \\
\text { çocuklar }\end{array}$ & 711 & 21,9 \\
\hline Ar1 sokmasına bağlı görülen reaksiyon & & \\
\hline Lokal (normal) & 1964 & 60,5 \\
\hline Geniş lokal & 19 & 0,6 \\
\hline Sistemik & 9 & 0,3 \\
\hline $\begin{array}{l}\text { Ailede arı alerjisi öyküsü (geniş lokal } \\
\text { veya sistemik reaks.) }\end{array}$ & 124 & 3,8 \\
\hline Çocukta alerjik hastalık öyküsü & 409 & 12,6 \\
\hline Ailede alerjik hastalık öyküsü & 604 & 18,6 \\
\hline
\end{tabular}

$* \mathrm{AO} \pm \mathrm{SH}=$ aritmetik ortalama \pm standart hata

Genel çalışma populasyonu içinden ayrılarak yaşam boyu en az bir kez arı tarafından sokulma tanımlayan 1992 çocuk $(\% 61,4)$ kendi içinde incelendiğinde (Tablo 2), yaşam boyu en az bir kez arı tarafindan sokulmuş olan 1992 çocuğun 1964 'ünde $(\% 98,6)$ lokal reaksiyon, 19’unda (\%0,95) geniş lokal reaksiyon, 9'unda $(\% 0,45)$ ise sistemik reaksiyon görüldüğü saptandı. Yaşam boyu arı tarafindan sokulma sayısı ortalaması 2,31 $\pm 0,05$ olarak bulundu. Son 12 ay içinde arı tarafından sokulma oranı $\% 35,6(\mathrm{n}=711)$, son 12 ay içinde arı tarafindan ortalama sokulma sayıs $0,50 \pm 0,01$ idi. Arı sokmalarından sorumlu arı cinsleri arı sokmalarının bir kısmında belirlenememişti, arı cinsleri tanımlanabilen arı sokma olaylarında, bal arılarının yaban arılarına göre daha yüksek oranda arı sokmalarından sorumlu olarak bildirildiği saptandı. Çocukların 91'inin $(\% 4,6)$ ailelerinde arı alerjisi öyküsü (arı sokmasına bağlı geniş lokal veya sistemik reaksiyon) vardı. Çocukların 258'inde (\%13), ailelerinin 377'sinde $(\% 18,9)$ alerjik hastalık öyküsü bulunuyordu (Tablo 2). 
Tablo 2. Yaşamları boyunca en az bir kez arı tarafindan sokulmuş olan grubun ( $\mathrm{n}=1992)$ verileri.

\begin{tabular}{|c|c|c|}
\hline & $\mathbf{n}$ & $\%$ \\
\hline Yaş ortalaması $(\mathrm{AO} \pm \mathrm{SH})^{*}$ & $10,18 \pm 0,05$ & \\
\hline \multicolumn{3}{|l|}{ Cinsiyet } \\
\hline Erkek & 1170 & 58,7 \\
\hline $\mathrm{K} 1 \mathrm{z}$ & 822 & 41,3 \\
\hline \multicolumn{3}{|l|}{ Yaşam boyu arı sokma sayısı (AO $\pm \mathrm{SH})$} \\
\hline & $2,31 \pm 0,05$ & \\
\hline \multicolumn{3}{|l|}{ Son 12 ayda arı sokma öyküsü olan çocuklar } \\
\hline & 711 & 35,6 \\
\hline \multicolumn{3}{|l|}{ Son 12 ayda arı sokma sayısı $(\mathrm{AO} \pm \mathrm{SH})$} \\
\hline & $0,50 \pm 0,01$ & \\
\hline \multicolumn{3}{|l|}{ Yaşam boyu arı sokma; arı cinsleri } \\
\hline Bal arıs1 & 995 & 49,9 \\
\hline Yaban arıs1 & 376 & 18,8 \\
\hline Her iki cins arı & 251 & 12,6 \\
\hline Bilinmeyen & 370 & 18,6 \\
\hline \multicolumn{3}{|l|}{ Son 12 ayda sokan arıların cinsleri } \\
\hline Bal aris1 & 320 & 16,0 \\
\hline Yaban aris1 & 199 & 9,98 \\
\hline Her iki cins arı & 31 & 1,6 \\
\hline Bilinmeyen & 161 & 8,08 \\
\hline \multicolumn{3}{|l|}{ Ar1 sokmasına bağlı görülen reaksiyon } \\
\hline Lokal (normal) & 1964 & 98,6 \\
\hline Geniş lokal & 19 & 0,95 \\
\hline Sistemik & 9 & 0,45 \\
\hline $\begin{array}{l}\text { Ailede arı alerjisi öyküsü (geniş lokal veya sistemik } \\
\text { reaks.) }\end{array}$ & 91 & 4,6 \\
\hline Çocukta alerjik hastalık öyküsü & 258 & 13,0 \\
\hline Ailede alerjik hastalık öyküsü & 377 & 18,9 \\
\hline
\end{tabular}

$* \mathrm{AO} \pm \mathrm{SH}=$ Aritmetik ortalama \pm Standart hata 
Genel çalışma populasyonu erkek ve kız cinsiyetlerine göre iki gruba ayrılarak değerlendirildiğinde ise (Tablo 3), erkek çocuklar yaşamları boyunca \%68,3 oranında (yaşam boyu prevalans) en az bir kez arı tarafindan sokulma tanımlarken, kız çocuklarında ise bu oran daha düşüktü $(\% 53,9)(p<0,001)$. Ek olarak erkek çocukları yaşamları boyunca daha yüksek arı tarafından sokulma sayısına sahipti (erkekler

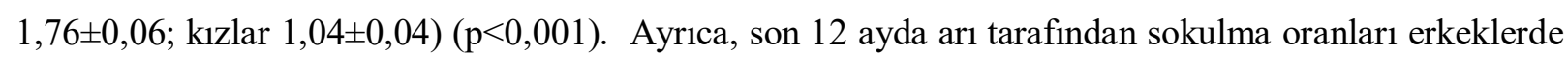
daha yüksek bulundu (erkekler \%26,7, kızlar \%16,6) ( $<<0,001)$. Son 12 ay içinde erkek çocukların arı tarafindan ortalama sokulma sayısı da daha yüksekti (erkekler $0,38 \pm 0,02$; kızlar $0,22 \pm 0,02)(p<0,001)$. Erkek çocuklar yaşamları boyunca daha yüksek oranda yaban arısı ve her iki cins arı tarafindan sokulma tanımliyorlardı $(\mathrm{p}<0,001)$.

Tablo 3. Erkek ve kız çocuklarda saptanan veriler $(n=3243)$.

\begin{tabular}{|c|c|c|c|c|c|}
\hline & $\begin{array}{c}\text { Erkek } \\
(\mathbf{n}=171 \\
\mathbf{n}\end{array}$ & $\%$ & $\begin{array}{c}\text { Kiz } \\
(\mathbf{n}=152 \\
n\end{array}$ & $\%$ & $\mathbf{p}^{*}$ \\
\hline Yaş $(\mathrm{AO} \pm \mathrm{SH})$ *** & \multicolumn{2}{|c|}{$9,92 \pm 0,06$} & \multicolumn{2}{|c|}{$9,66 \pm 0,06$} & $<0,01$ \\
\hline Yaşam boyu arı sokma & 1169 & 68,3 & 823 & 53,9 & $<0,001$ \\
\hline $\begin{array}{l}\text { Yaşam boyu arı sokma } \\
\text { sayısı }(\mathrm{AO} \pm \mathrm{SH})\end{array}$ & \multicolumn{2}{|c|}{$1,76 \pm 0,06$} & \multicolumn{2}{|c|}{$1,04 \pm 0,04$} & $<0,001$ \\
\hline $\begin{array}{l}\text { Son } 12 \text { ayda arı sokma } \\
\text { sayıs1 }(\mathrm{AO} \pm \mathrm{SH})\end{array}$ & \multicolumn{2}{|c|}{$0,38 \pm 0,02$} & \multicolumn{2}{|c|}{$0,22 \pm 0,02$} & $<0,001$ \\
\hline $\begin{array}{l}\text { Son } 12 \text { ayda arı sokma } \\
\text { öyküsü olan çocuklar }\end{array}$ & 457 & 26,7 & 254 & 16,6 & $<0,001$ \\
\hline \multicolumn{6}{|l|}{$\begin{array}{l}\text { Ar1 sokmasına } \text { bağlı } \\
\text { görülen reaksiyon }\end{array}$} \\
\hline Lokal & 1145 & 66,9 & 819 & 53,6 & $<0,001$ \\
\hline Geniş lokal & 16 & 0,9 & 3 & 0,2 & $<0,01$ \\
\hline Sistemik & 8 & 0,5 & 1 & 0,1 & $<0,05$ \\
\hline $\begin{array}{l}\text { Ailede arı alerjisi öyküsü } \\
\text { (geniş lokal veya sistemik } \\
\text { reaks.) }\end{array}$ & 72 & 4,2 & 52 & 3,4 & $>0,05$ \\
\hline $\begin{array}{l}\text { Çocukta alerjik hastalık } \\
\text { öyküsü }\end{array}$ & 208 & 12,1 & 201 & 13,1 & $>0,05$ \\
\hline $\begin{array}{l}\text { Ailede alerjik hastalık } \\
\text { öyküsü }\end{array}$ & 297 & 17,3 & 307 & 20,1 & $>0,05$ \\
\hline
\end{tabular}

$* \mathrm{p}=$ istatistiksel anlamlılı seviyesi

$* * \mathrm{AO} \pm \mathrm{SH}=$ aritmetik ortalama \pm standart hata 
Arı sokmasına bağlı sistemik reaksiyonlar erkek çocuklarda istatistiksel anlamlı daha yüksek oranlarda; erkeklerde \%0,5, kızlarda ise \%0,1 oranında saptanmıştı $(\mathrm{p}<0,05)$. Geniş lokal reaksiyonlar da benzer şekilde erkeklerde kızlardan daha yüksek sıklıkta görülmüştü $(\% 0,9 / \% 0,2, \mathrm{p}<0,01)$. Erkek ve kızlar arasında ailede arı alerjisi öyküsü, çocukta veya ailesinde alerjik hastalık öyküsü görülme oranlarında ise anlamlı farkl111klar saptanmadı $(\mathrm{p}>0,05)$.

\section{TARTIŞMA}

Avrupa ülkelerinde arı venom allerjisinin en siklıkla bal arıs1 (Apis mellifera-honey bee), yaban arılarından Vespula (V.germanica, V.vulgaris) ve Akdeniz ülkelerinde ek olarak Polistes (P.gallicus, P.dominulus) türü arıların sokmaları sonucu görüldüğü bildirilmektedir (30,31). Nadir olarak da diğer Vespula türleri (Dolichovespula spp.), Vespa crabro, Bombus (bumble bee) türü arıların sokmaları sonucu görülmektedir (30,31).

Çalışmamızda 6-15 yaş grubu çocuklarda yaşam boyu sistemik reaksiyon görülme prevalansı \%0,3 olarak bulundu ve yurtdışında çocuk populasyonları içinde hepsi anket yöntemi ile yapılmış olan diğer çalışma sonuçları $(\% 0,15-\% 2,5)$ ile genel olarak benzer olduğu görüldü (14-16,26-29). İtalya' da Novembre ve ark. (29), 1175 ilkokul çocuğunda anket yöntemiyle \%0,34 oranında sistemik reaksiyon bildirmişlerdir. ABD' de Settipane ve Boyd (26), 11-16 yaş grubu 4994 erkek izci çocuk üzerinde anket yöntemiyle \%0,8, sağlık personelinin çocuklarla yüz yüze görüşerek yaptıkları araştırmada ise $\% 0,3$ oranında sistemik reaksiyon bulunduğunu bildirmişlerdir. Settipane ve ark. (27) ise, 2694 erkek izci çocukta anket yöntemiyle $\% 3,9$, sağlık personelinin çocuklarla yüz yüze görüşerek yaptıkları araştırmada ise $\% 0,8$ oranında sistemik reaksiyon bulunduğunu bildirmişlerdir. Yine ABD'de Abrishami ve ark. (28), 7-16 yaş grubu 2010 kız izci üzerinde anket yöntemiyle \%0,9, sağlık personelinin çocuklarla yüz yüze görüşerek yaptıkları araştırmada ise \%0,15 oranında sistemik reaksiyon bulunduğunu bildirmişlerdir. Çocukluk yaş grubunda anket yöntemi ile son 10 yılda yapılan yeni çalışmalarda ise; İtalya'da 1035 çocukta \%0,5 (14), İsrail'de on bin yirmi bir 13-14 yaş grubu çocukta \% 2,5 orta-şiddetli sistemik reaksiyon (15), İrlanda' da 6-8 ve 11-13 yaş gruplarındaki 4112 okul çocuğunda \%1,3 hafif (kutanöz) sistemik reaksiyon ve \%0,2 orta/şiddetli sistemik reaksiyon (16) oranları bildirilmiştir. Arı sokmaları ile karşılaşılma iklim, bölge, çevre şartları ve yaşam tarzı gibi çeşitli faktörlere bağlı olarak değişmektedir $(13,30)$. İskandinav ülkeleri gibi soğuk ve yağışlı iklime sahip bölgelerde yaşayan insanlar, Akdeniz bölgesi ülkelerine göre arı türleri ile daha az oranda karşılaşmaktadırlar (13). İsveç’in kuzey bölgelerinde yaşayan erişkinlerde güney bölgelerinde yaşayanlara göre arı venom alerjenlerine spesifik IgE sonuçları ile daha düşük oranda duyarlılık bulunduğu bildirilmiştir (21). Akdeniz bölgesi ülkelerinde yaşayan erişkinler ise daha yüksek oranda arı sokmaları ile karşılaşmakta, daha yüksek reaksiyon ve duyarlılık oranları bildirilmektedir $(13,32)$. Ülkemiz iklim koşulları ve insanların yaşam şartları, arı sokmaları ile karşılaşılma bakımından Kuzey Avrupa ve İskandinav ülkeleri gibi bölgelere göre daha uygun şartlara sahiptir. Bu nedenlerle ülkemiz çocuklarının arılar ile karşılaşma olasılıklarının ve buna paralel olarak arı sokmalarına bağlı 
reaksiyonların görülme riskinin daha yüksek olabileceği düşünülebilir. Türkiye'de çocuklar üzerinde yapılmış olan tek çalışmada, 1998 yılında Ankara il merkezinde 6-13 yaş grubu 738 ilkokul öğrencisinde anket yöntemiyle $\% 2$ oranında sistemik reaksiyon bildirilmiştir (25). Bu çalışmamızda Marmara bölgesinde bulunan Bursa ilinde çocukların dikkate değer oranda arı sokmaları ve buna bağlı geniş lokal ve sistemik (anafilaksi) reaksiyonlar ile karşılaştığı belirlenmiştir. Türkiye'nin diğer bölgeleri ve geneli hakkında verilerin elde edilmesi için ise gelecekte başka çalışma sonuçlarına ihtiyaç olduğu düşünülmüştür.

Literatürde erişkin yaş grubunda ise genel populasyonlar üzerinde çoğunluğu anket yöntemiyle yapılmış çalışmalarda sistemik reaksiyon görülme oranları \%1,16-4 arasında ve çocukluk çağında yapılan araştırmalara göre genel olarak daha yüksek oranlarda bildirilmektedir; ABD' de Golden ve ark. (20) 187 işçide \%4, 1989'da ise 269 fabrika işçisinde \%3,3 (34), Kanada'da Herbert ve ark. (11) 86 erkek ofis çalışanında \%1,2, Avustralya'da Stuckey ve ark. (10) 3679 erişkinde \%2,7, İsviçre'de Müller (9) 1598 erişkinde \%1,3, Fransa' da Charpin ve ark. (12) 2067 erişkinde \%1,16, İspanya'da Fernandez ve ark. (32) yaş ortalaması 42,4 olan 303 erişkinde (56's1 20 yaş altı) \%2,3, İsveç’te Björnsson ve ark. (21) 1815 erişkinde \%1,5, Almanya'da Schafer ve ark. (19) 232 erişkin ve 45 çocuktan oluşan 277 kişide \%3,3, Yunanistan'da Grigoreas ve ark. (13) 480 erişkinde \%3,1 olarak bildirmişlerdir. Diğer yandan Chaffee (22) 3705 astım veya allerjik rinitli olguda \%0,38 oranında ağır sistemik reaksiyon bildirmiştir. Ülkemizde ise erişkin yaş grubunda yapılmış çalışmalarda; Kalyoncu ve ark. (23) 1997'de Afyon ili Çay ilçesinde 786 kağıt fabrikası işçisinde (yaş ortalaması 40,6, 27'si 16 yaş üzeri) anket yöntemiyle \%7,5 oranında sistemik reaksiyon (hafif \%5,3, ağır \%2,2) bildirmişlerdir. Şimşek ve ark. (24) Sivas ili Zara ilçesinde 757 erişkinde anket yöntemiyle \%4,1 oranında sistemik reaksiyon bildirmişlerdir. Türkiye'de ve diğer ülkelerde erişkin yaş grubunda yapılmış çalışma sonuçlarında, çocukluk yaşlarında yapılan çalışmalara göre genel olarak belirgin daha yüksek sistemik reaksiyon oranları saptandığı gözlenmektedir. Türkiye' de çocukluk çağında arı sokmaları sonrasında geniş lokal reaksiyon görülme prevalansı ile ilgili araştırma sonuçları literatürde mevcut değildir, Türkiye'den bildirilen ilk veri olarak bu çalışmada yaşam boyu geniş lokal reaksiyon prevalansı verisi \%0,6 olarak saptanmıştır. Literatürde çocuk genel populasyonlar üzerinde, geniş lokal reaksiyon görülme prevalansı ile ilgili diğer ülkelerde yapılan çalışmalar da az sayıdadır; İtalya'da \% 0,9 (14), İsrail'de \% 11,5 (15), İrlanda'da \% 2,2 (16) olarak bildirilmiştir. Erişkin genel populasyonlarda ise geniş lokal reaksiyon prevalansının çocukluk çağ 1 çalışmalarına göre daha yüksek olarak genellikle \%1.5-7,4 arasında görüldüğü bildirilmektedir (9-13). Grigoreas ve ark. (13) 480 erişkin olguda \%4,6, Müller (9) \%1,5, Stuckey ve ark. (10) \%3,1, Herbert ve ark. (11) \%2,3, Charpin ve ark. (12) \%7,4 oranlarında geniş lokal reaksiyon saptandığını bildirmişlerdir. Ayrıca Golden ve ark. (33) \%18,6 ve Fernandez ve ark. (32) kırsal bölgede yaşayan 303 erişkinde \%26,4 gibi yüksek oranlar da bildirmişlerdir.

Yaşam boyu en az bir kez arı tarafindan sokulan 1992 çocuk kendi içlerinde incelendiğinde, arı cinsleri tanımlanabilen arı sokma olaylarında, bal arılarının yaban arılarına göre daha yüksek oranda arı 
sokmalarından sorumlu olarak bildirildiği görüldü. Ankara'da çocuklarda yapılan çalışmada da benzer sonuçlar bildirilmiş olup, burada sunulan çalışmada da elde edilen sonuçlara göre, bal arıları arı sokmalarından sorumlu arılar içinde en sık görülen tür olarak dikkati çekmektedir (25). Ayrıca Türkiye' de, erişkinlerde yapılan bir çalışmada yaşam boyu ortalama arı sokma sayısı 14,4 449,4 olarak,

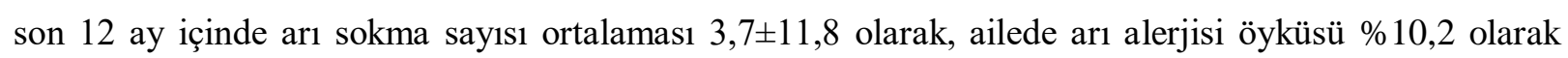
bildirilmiştir (23). Bu çalışmada ise çocuklarda aynı sonuçlar erişkin yaşlarda saptanan rakamlara göre belirgin daha düşük olarak bulunmuştur.

$\mathrm{Bu}$ çalı̧̧mada erkek çocuklarda sistemik reaksiyon ve geniş lokal reaksiyon görülme oranları kız çocuklara göre istatistiksel anlamlı olarak daha yüksek oranlarda bulunmuştur. Çalışmamızda bölgemizdeki çocukların yaşam boyu en az bir kez arı tarafindan sokulma sıklığı \%61,4 gibi yüksek bir rakamda (erkeklerde \%68,3, kızlarda 53,9) bulunmuştur. Ankara il merkezinde 6-13 yaş grubundaki çocuklarda yaşam boyu en az bir kez arı tarafından sokulma sıklığı benzer olarak \%60,8 (erkeklerde \%67, kızlarda \%55) olarak bildirilmiştir (25). Bu çalışmada erkeklerde yaşam boyu arı sokma sayıları $1,76 \pm 0,06$, kızlarda ise $1,04 \pm 0,04$ olarak bulunurken, Ankara'da yapılan çalışmada ise yaşam boyu arı

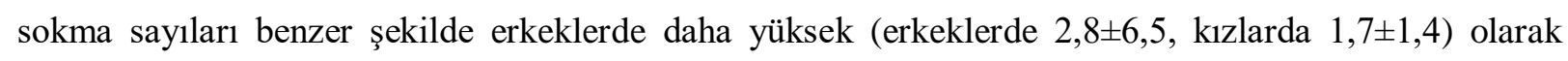
bildirilmiştir (25). Türkiye'de bu konuda daha önce yapılmış olan tek çalışmada ve sunulan bu çalışmada da görüldügü gibi, ülkemizde erkek çocuklar arılar tarafindan daha fazla sayıda sokulmaya maruz kalmaktadırlar. Arı sokmalarına daha yüksek sıklıkta maruziyete bağlı olarak erkek çocuklarda daha yüksek oranda sistemik reaksiyon ve geniş lokal reaksiyon görülmüş olabileceği düşünülmüştür.

Sonuç: Bölgemizde yaşayan 6-15 yaş grubu çocuklar arı sokmaları ile sık olarak karşılaşmaktadır. Arı sokmalarında en sık rastlanan arı cinsinin bal arısı olduğu belirlenmiştir. Genel çocuk populasyonunda arı sokmaları sonrası gelişen sistemik reaksiyonların yaşam boyu çocuklarda görülme sıklı̆̆ \%0,3 saptanırken, Türkiye'de ilk kez bildirilen bir veri olarak geniş lokal reaksiyonlar ise \%0,6 oranında saptanmıştır. Ek olarak yaşam boyu en az bir kez arı tarafından sokulmuş olan çocuklarda ise geniş lokal reaksiyonların yaşam boyu prevalans $1 \% 0,95$, sistemik reaksiyonların yaşam boyu prevalansı ise \%0,45 oranında saptanmıştır. Erkek çocukların kız çocuklara göre arı sokmalarına ve ilişkili reaksiyonlara daha yüksek oranda maruz kaldıkları saptanmıştır. Bu çalışmada Bursa ilinde çocukların dikkate değer oranda arı sokmaları ve buna bağlı geniş lokal ve sistemik (anafilaksi) reaksiyonlar ile karşılaştığı belirlenmiştir. Bölgemizdeki çocuklar arı sokmalarına bağlı olarak gelişebilecek reaksiyonlar için potansiyel riskler taşımaktadırlar, bu verilerin olası reaksiyonları tanımlama ve yaklaşım açısından dikkate alınması uygun olacaktır. Bu konuda Türkiye'nin diğer bölgeleri ve geneli hakkında verilerin elde edilmesi için yeni çalışmalara ihtiyaç olduğu düşünülmüştür.

Çalışmanın kısıtlılıkları: Geniş populasyonlarda yapılan prevalans çalışmalarında anket yöntemi geçerli kabul edilmekte ve yaygın olarak kullanılmaktadır. Ancak anket yöntemi ile yapılan tüm çalışmalarda populasyonda yer alan bireylerin sosyokültürel düzeyleri, tanımlama ve anımsama problemleri sonuçları etkileyebilmektedir. 
Çıkar çatışması: Yoktur

Finansman desteği: Yoktur

\section{KAYNAKLAR}

1- Golden DBK. Insect Allergy. In: O'Hehir RE, Holgate ST, Sheikh A (eds). Middleton's Allergy Essentials. Edinburgh : Elsevier; 2017. p. 377-393.

2- Bilo BM, Bonifazi F. Epidemiology of insect-venom anaphylaxis. Current Opinion in Allergy and Clinical Immunology 2008;8:330-337.

3- Pumphrey RSH, Stanworth SJ. The Clinical Spectrum of Anaphlaxis in North-West England. Clin Exp Allergy 1996;26:1364-70.

4- Reissman RE. Stinging Insect Allergy. Immunology and Allergy Clinics of North America 1992;76:883-94.

5- Graham DM, McPherson H, Lieberman P. Skin Testing in the Evaluation of Hymenoptera Allergy and Drug Allergy. Immunology and Allergy Clinics of North America 2001; 21:301-20.

6- Yunginger JW. Insect allergy (Adults and Children). In: Bierman CW, Pearlman DS (eds). Allergic diseases from infancy to adulthood. Philadelphia: WB Saunders Co.; 1988. p.678-83.

7- Reisman RE. Allergy to stinging insects. In: Paterson R, Grammer LC, Greenberger PA (eds). Allergic diseases. Philadelphia: Lippincott-Raven Publ.; 1997. p.253-64.

8- Mauriello PM, Barde SH, Georgitis JW, Reisman RE. Natural history of large local reactions from stinging insects. J Allergy Clin Immunol 1984;74:494-8.

9- Müller U. Diagnose und therapie der insekten stichallergie heute. Allergologie 1981;4:51-5.

10- Stuckey M, Cobain T, Sears M, et al. Bee venom hypersensitivity in Busselton. Lancet 1982;2:41.

11- Herbert FA, Salkie ML. Sensitivity to Hymenoptera in adults males. Ann Allergy 1982;48:12-3.

12- Charpin D, Vervloet D, Haddi E, Segalen C, et al. Prevalence of allergy to Hymenoptera stings. Allergy Proc 1990;11:29-32.

13- Grigoreas Ch, Galatas ID, Kiamouris Ch, Papaioannou D. Insect-venom allergy in Greek adults. Allergy 1997;52: 51-7.

14- Quercia O, Incorvaia C, Marseglia GL, Puccinelli P, Dell'albani I, Emiliani F, Frati F, Stefanini GF. Prevalence and incidence of reactions to insect stings in children: a reappraisal. Minerva Pediatrica 2014;66(4):257-60.

15- Graif Y, Romano-Zelekha O, Livne I, Green MS, Shohat T. Allergic reactions to insect stings: Results from a national survey of 10,000 junior high school children in Israel.

J Allergy Clin Immunol 2006;117:1435-9. 
16- Jennings A, Duggan E, Perry IJ, Hourihane JO-B. Epidemiology of allergic reactions to hymenoptera stings in Irish school children. Pediatr Allergy Immunol 2010:21:1166-1170.

17- Sin B. Böcek allerjisi. In: Aydilek R (ed). Allerjik hastalıklar ve bronşial astma. Aktüel Tıp Dergisi 1998; I:179-204.

18- Day JH, Buckeridge DL, Welsh AC. Risk assesment in determining systemic reactivity to honeybee stings in sting-threatened individuals. J Allergy Clin Immunol 1994;93:691-705.

19- Mosbech H. Death caused by wasp and bee stings in Denmark, 1960-80. Allergy 1983; 38:195-200.

20- Golden DBW, Valentine MD, Kagey-Sobotka A, Lichtenstein LM. Prevalence of Hymenoptera venom allergy. J Allergy Clin Immunol 1982;69 (Abstracts): 124.

21- Björnsson E, Janson C, Plaschke P, Norrman E, Sjöberg O. Venom allergy in adult Swedes: a population study. Allergy 1995;50:800-5.

22- Chaffee FH. The prevalence of beesting allergy in an allergic population. Acta Allergol 1970;25:2923.

23- Kalyoncu AF, Demir AU, Özcan Ü, Özkuyumcu C, Şahin AA, Barış Yİ. Bee and wasp venom allergy in Turkey. Ann Allergy Asthma Immunol 1997;78:408-12.

24- Şimşek M, Seyfikli Z, Akkurt İ, Abadoğlu Ö. Sivas ili, Zara ilçesinde arı allerjisi prevalansı. T Klin J Allergy-Asthma 2000;2:127-32.

25- Kalyoncu AF. The prevalence of Hymenoptera stings and allergy in primary school children in Ankara. Int Rev Allergol Clin Immunol 1998;4:135-7.

26- Settipane GA, Boyd GK. Prevalence of bee stings allergy in 4992 boy scouts. Acta Allergol 1970;25:286.

27- Settipane GA, Newstead GJ, Boyd GK. Frequency of Hymenoptera allergy in an atopic and normal population. J Allergy Clin Immunol 1972;50:140-50.

28- Abrishami MA, Boyd GK, Settipane GA. Prevalence of bee stings allergy in 2010 girl scouts. Acta Allergol 1971;26:117-20.

29- Novembre E, Cianferoni A, Bernardini R, et al. Epidemiology of insect venom sensitivity in children and its correlation to clinical and atopic features. Clin Exp Allergy 1998;28:834-8.

30- Müller UR (ed). Insect sting allergy. Clinical Picture, diagnosis and treatment. Stutgart, New York: Gustav Fischer Verlag; 1990. p.27-36.

31- Bousquet J, Menardo JL, Michel F. Allergies aux Hymenopteres. Joinville-le-pont: Institut Français de Recherche en Allergologie, 1985.

32- Fernandez J, Blanca M, Soriano V, Sanchez J, Juarez C. Epidemiological study of the prevalence of allergic reactions to Hymenoptera in a rural population in the Mediterranean area. Clin Exp Allergy 1999;29:1069-74.

33- Golden DBK, Marsh DG, Kagey-Sobotka A, et al. Epidemiology of insect venom sensitivity. JAMA 1989;262:240-4. 